\title{
Leszek Mitrus
}

Uniwersytet Jagielloński

leszek.mitrus@uj.edu.pl

\section{Praca zarobkowa a bezpieczeństwo socjalne (uwagi na tle przekształceń rynku pracy)}

\author{
Paid Work and Social Security (Remarks Against the Background \\ of Labour Market Transformation)
}

\section{STRESZCZENIE}

Niniejszy tekst jest poświęcony analizie przekształceń rynku pracy, począwszy od kodyfikacji polskiego prawa pracy do czasów współczesnych. Autor wskazuje, że prawna forma prowadzonej działalności zarobkowej przesądza o statusie danej osoby, zarówno w kontekście stabilizacji zatrudnienia, jak i ochrony z zakresu ubezpieczeń społecznych. W realiach gospodarki centralnie sterowanej umowa o pracę na czas nieokreślony stanowiła podstawową formę działalności zarobkowej. Obecnie współistnieją jednak różne formy świadczenia pracy zarobkowej, często pozostające poza zakresem prawa pracy. Autor zwraca uwagę na głęboką segmentację współczesnego rynku pracy, a także na fakt, że praca zarobkowa często nie zapewnia stabilizacji życiowej ani odpowiedniego poziomu bezpieczeństwa socjalnego.

Słowa kluczowe: praca zarobkowa, stosunek pracy, nowe formy zatrudnienia, zabezpieczenie społeczne, rynek pracy, praca prekaryjna

Tematem zaproponowanym przez inicjatorów księgi jubileuszowej Profesor Teresy Liszcz są przemiany w prawie pracy od jego kodyfikacji do czasów współczesnych. Bez wątpienia uchwalenie w dniu 26 czerwca 1974 r. Kodeksu pracy ${ }^{1}$, który wszedł w życie z dniem 1 stycznia 1975 r., stanowi istotną cezurę w rozwoju naszego ustawodawstwa pracy. Truizmem jest przy tym spostrzeżenie, że kodeks powstał $\mathrm{w}$ zupełnie innej rzeczywistości, a nie wszystkie instytucje przetrwały

${ }^{1}$ Pierwotny tekst Kodeksu pracy został opublikowany w Dz. U. z 1974 r., nr 24, poz. 141. Obecnie zob. t.j. Dz. U. z 2014 r., poz. 1502. 
próbę czasu. Świadczy o tym dobitnie fakt, że wskazany akt prawny był nowelizowany ponad 100 razy. Dotychczasowe modyfikacje kodeksu miały miejsce zwłaszcza w kontekście jego dostosowywania do realiów gospodarki rynkowej po przełomie z 1989 r., a także zapewnienia zgodności uregulowań krajowych ze standardami europejskimi w związku z dążeniami Polski do uzyskania członkostwa w Unii Europejskiej. W okresie ponad 40 już lat obowiązywania kodeksu, przekształcenia w dziedzinie zatrudnienia można więc uznać za fundamentalne. Należy zresztą oczekiwać kolejnych nowelizacji w naszym prawie pracy, choćby ze względu na konieczność zapewnienia zgodności regulacji krajowych z wymogami Unii Europejskiej. Ponadto aktualnym zagadnieniem pozostaje kwestia uchwalenia nowego kodeksu pracy, który systemowo oraz całościowo uregulowałby problematykę zatrudnienia $\mathrm{w}$ realiach społecznej gospodarki rynkowej.

Praca zarobkowa stanowi nie tylko źródło regularnego dochodu, ale jest również wyznacznikiem szeregu uprawnień, zarówno wynikających z prawa pracy, jak i prawa ubezpieczeń społecznych. O ile w chwili uchwalenia Kodeksu pracy dominujące znaczenie przypadało zatrudnieniu pracowniczemu, o tyle współczesny rynek pracy jest znacznie bardziej zróżnicowany. Dlatego podejmując problematykę przekształceń prawa pracy w ostatnich kilku dekadach, chciałbym skoncentrować się na relacjach między pracą zarobkową a bezpieczeństwem socjalnym. Ze względu na coraz większe zróżnicowanie form świadczenia pracy, w tytule opracowania świadomie nawiązuję do „pracy zarobkowej”, nie ograniczając się do „zatrudnienia” w rozumieniu Kodeksu pracy.

Powstaje bowiem fundamentalne pytanie, czy i w jakim zakresie wykonywanie pracy zarobkowej zapewnia danej osobie odpowiednią ochronę socjalną. Mam tu na myśli zarówno stabilizację zatrudnienia, rozumianą jako ochronę przed wypowiedzeniem, jak i związane z pracą zarobkową uprawnienia z zakresu ubezpieczeń społecznych. Chodzi przede wszystkim o świadczenia na wypadek choroby lub macierzyństwa, a także długoterminową perspektywę uzyskania w przyszłości emerytury. Inaczej mówiąc, rozważenia wymaga, jakie znaczenie dla statusu socjalnego jednostki ma forma prawna prowadzonej działalności zarobkowej. Pojawia się też kwestia oceny adekwatności obowiązujących uregulowań do wymogów współczesności oraz celowości ewentualnych zmian legislacyjnych.

Wśród licznych zmian ustanowionych kodyfikacjąa ${ }^{2}$ warto uwypuklić ustanowienie jednolitego statusu pracowniczego. W preambule kodeksu wprost pod-

\footnotetext{
${ }^{2}$ Ich analizę w piśmiennictwie tego okresu zob. np. W. Jaśkiewicz, Zagadnienia ogólne kodeksu pracy, [w:] Studia nad kodeksem pracy, red. W. Jaśkiewicz, Poznań 1976, s. 11 i nast.; J. Pacho, Przedmiot, system i funkcje prawa pracy, [w:] Nowe prawo pracy, red. R. Korolec, J. Pacho, Warszawa 1975, s. 9 i nast.
} 
kreślono, że znosi on różnicę w uprawnieniach pracowników fizycznych i umysłowych. Zrezygnowano zatem z rozróżnienia pomiędzy robotnikiem a pracownikiem umysłowym. Te podstawowe rozróżnienia dotyczyły przede wszystkim okresu wypowiedzenia umowy o pracę, długości urlopu oraz zachowania prawa do wynagrodzenia w określonych przypadkach niewykonywania pracy. Jednocześnie przepisom kodeksu nadano moc powszechnie obowiązującą w stosunku do wszystkich pracowników, dopuszczając w razie potrzeby możliwość rozwiązań szczególnych. ${ }^{3}$

Centralną kategorią indywidualnego prawa pracy jest stosunek pracy, przy czym umowa o pracę stanowi najczęstszą podstawę jego nawiązania. W ówczesnym piśmiennictwie zauważono, że umowa o pracę na czas nieokreślony w praktyce występowała najczęściej i spełniała istotną rolę w ramach funkcji ochronnej prawa pracy. ${ }^{4}$ Kodeks uzależnił dopuszczalność wypowiedzenia umów o pracę w zależności od ich rodzaju. Zgodnie z art. 32 każda ze stron mogła rozwiązać za wypowiedzeniem umowę o pracę zawartą na okres próbny, okres wstępny oraz czas nieokreślony. Ponadto możliwość wcześniejszego rozwiązania umowy na czas określony została przewidziana przez art. 33 k.p. Przepis ten w niezmienionym brzmieniu obowiązuje do dnia dzisiejszego. Przewiduje on, że przy zawieraniu umowy na czas określony, dłuższy niż sześć miesięcy, strony mogą przewidzieć dopuszczalność wcześniejszego rozwiązania tej umowy za dwutygodniowym wypowiedzeniem. Do problematyki związanej z klauzulą umowną, przewidującą dopuszczalność jednostronnego wypowiedzenia umowy na czas określony, wrócę jeszcze w dalszej części opracowania.

W okresie przedkodeksowym pracodawca dysponował swobodą rozwiązania umowy, z zastrzeżeniem ograniczeń wynikających z ochrony szczególnej. Nie było wymogu zachowania formy pisemnej ani podania przyczyny wypowiedzenia. Rady zakładowe związków zawodowych miały prawo interwencji u pracodawcy w sprawach zwolnienia, przy czym na mocy układów zbiorowych nierzadko przysługiwało im prawo wyrażenia sprzeciwu. Okresy wypowiedzenia były zróżnicowane w odniesieniu do robotników i pracowników umysłowych, a także rodzaju pracy lub branży ${ }^{5}$. Prawo pracy w zasadzie nie ograniczało kompetencji pracodawcy do wypowiedzenia umowy o pracę, byleby zachowane były warunki formalne oraz by wypowiedzenie nie było nadużyciem prawa. ${ }^{6}$

$\mathrm{Z}$ tej perspektywy nie sposób przecenić znaczenia ustanowienia wraz z kodyfikacją ochrony przed wypowiedzeniem. Artykuł 45 k.p. w swojej pierwotnej

${ }^{3}$ W. Muszalski, Polski kodeks pracy na tle kodyfikacji jego epoki, [w:] Prawo pracy w świetle procesów integracji europejskiej. Księga jubileuszowa Profesor Marii Matey-Tyrowicz, red. J. Wratny, M.B. Rycak, Warszawa 2011, s. 540.

${ }^{4}$ H. Lewandowski, Nawiazanie stosunku pracy, [w:] Nowe prawo pracy, s. 81.

${ }^{5}$ Tak: A. Walas, Prawo wypowiedzenia umowy o prace,, Kraków 1961, s. 92 i nast.

${ }^{6}$ W. Jaśkiewicz, op. cit., s. 19. 
wersji przyznał komisjom odwoławczym do spraw pracy kompetencję do uznania wypowiedzenia za bezskuteczne lub przywrócenia do pracy na poprzednich warunkach, jeżeli wypowiedzenie umowy o pracę na czas nieokreślony było nieuzasadnione. Jednocześnie art. $38 \S 1$ k.p. przewidywał, że o zamiarze wypowiedzenia pracownikowi umowy o pracę zawartej na czas nieokreślony kierownik zakładu pracy zawiadamiał na piśmie radę zakładową, podając przyczynę uzasadniającą rozwiązanie umowy. Warto w tym miejscu odnotować pogląd, że regulacja kodeksowa polega na wskazaniu uprawnień pracownika w razie wadliwego wypowiedzenia lub rozwiązania bez wypowiedzenia umowy o pracę przez zakład pracy i na określeniu istotnej treści orzeczenia organu rozstrzygającego spór w tym przedmiocie. ${ }^{7}$

Kodyfikacja wprowadziła zatem powszechną ochronę trwałości stosunku pracy. W jej skład weszły trzy zasadnicze elementy: zasadność wypowiedzenia, uprzednia kontrola zamiaru wypowiedzenia przez przedstawicielstwo pracownicze, a także następcza ocena zasadności oraz prawidłowości wypowiedzenia przez niezależny organ rozpatrujący spory ze stosunku pracy. ${ }^{8}$ Należy przy tym podkreślić, że wprowadzone wraz z kodyfikacją przepisy dotyczące stabilizacji zatrudnienia objęły swoim zakresem jedynie pracowników zatrudnionych na podstawie umowy o pracę zawartej na czas nieokreślony. Pomimo zmian wprowadzanych w późniejszym okresie, w zasadniczym kształcie model powszechnej ochrony przed wypowiedzeniem, przyjęty w latach 70 . ubiegłego wieku, obowiązuje do dnia dzisiejszego. ${ }^{9}$

Zarysowane wyżej uregulowania, wywodzące się sprzed czterech dekad, mają nadal zasadnicze znaczenie dla określenia sytuacji prawnej osób zatrudnionych. Na gruncie kodeksu wybór rodzaju umowy o pracę był i nadal jest pozostawiony uznaniu stron. W praktyce oznacza to, że najczęściej pracodawca narzuca rodzaj umowy o pracę. Kandydat z reguły stoi przed dylematem przyjęcia lub odrzucenia konkretnej oferty zatrudnienia. Tylko nieliczni uczestnicy rynku pracy, a mianowicie ci legitymujący się rzadkimi lub wysokimi kwalifikacjami, mogą pozwolić sobie na negocjowanie warunków zatrudnienia. Kwestia ta jest o tyle istotna, że - jak już wskazano - jedynie umowa na czas nieokreślony gwarantuje objęcie pracownika ochroną przed jednostronnym rozwiązaniem umowy przez pracodawcę.

Regulacje prawa pracy, przyjęte w latach 70 . ubiegłego wieku, były tworzone z myślą o gospodarce centralnie sterowanej. Były one znacznie bardziej sztywne

${ }^{7}$ T. Liszcz, Nieważność czynności prawnych w umownych stosunkach pracy, Warszawa 1977, s. 219.

${ }^{8} \mathrm{~W}$ pierwotnej wersji kodeksu była to komisja odwoławcza do spraw pracy, obecnie kompetencja ta przysługuje sądom pracy.

${ }^{9}$ Szerzej zob. zwłaszcza: A. Dral, Powszechna ochrona trwałości stosunku pracy. Tendencje zmian, Warszawa 2009, s. 145 i nast.; A. Rycak, Powszechna ochrona trwałości stosunku pracy, Warszawa 2013, s. 84 i nast. 
niż obecnie, a partnerom społecznym czy samym stronom stosunku pracy pozostawiały zdecydowanie mniej swobody uznania. Ponadto umowa o pracę na czas nieokreślony była dominującą oraz najczęstszą formą prowadzenia działalności zarobkowej. Nierzadko modelem kariery zawodowej było zatrudnienie „od matury do emerytury" w tym samym zakładzie pracy, z reguły w dużym przedsiębiorstwie państwowym. Skądinąd ,nadmierna fluktuacja kadr” była postrzegana jako zjawisko niepożądane, a rozwiązanie umowy przez pracownika lub pozostawanie bez zatrudnienia przez pewien czas mogło skutkować ograniczeniem lub utratą niektórych praw pracowniczych. ${ }^{10}$

Działalność zarobkowa jest również podstawowym wyznacznikiem ochrony z zakresu ubezpieczeń społecznych. Ubezpieczenia społeczne opierają się m.in. na zasadzie powszechności, czyli objęcia swoim zakresem ogółu pracującej ludności, co zarazem nie wyklucza zróżnicowania statusu prawnego poszczególnych osób świadczących pracę. ${ }^{11}$ Pracownicy byli oraz pozostają osobami korzystającymi z najdalej idącej ochrony ubezpieczeniowej. W tym kontekście można mówić o pracowniczym stosunku ubezpieczenia społecznego. ${ }^{12}$ Model ubezpieczeń, oparty na preferowaniu osób zatrudnionych w ramach stosunku pracy, mógł znajdować swoje uzasadnienie wówczas, gdy dominującą oraz niekwestionowaną przewagę na rynku pracy miała właśnie umowa o pracę, co odpowiadało rzeczywistości gospodarki centralnie sterowanej. Jednocześnie ekspansja ubezpieczeń społecznych charakteryzuje się rozszerzaniem swojego zakresu podmiotowego oraz obejmowaniem ochroną coraz to nowych ryzyk ubezpieczeniowych. ${ }^{13}$

Można zatem stwierdzić, że w realiach gospodarki centralnie sterowanej rynek pracy był w znacznym stopniu zuniformizowany. Dominującą oraz najczęściej stosowaną podstawą świadczenia pracy zarobkowej była umowa o pracę na czas nieokreślony. Zdecydowanej większości osób świadczących pracę gwarantowała ona zarówno stabilizację zatrudnienia, jak i pełną ochronę z zakresu ubezpieczeń społecznych. W praktyce mniejsze znaczenie odgrywały umowy o pracę na czas określony. Z kolei umowy cywilnoprawne dotyczyły przede wszystkim działań jednorazowych lub krótkotrwałych, z reguły stanowiąc dodatkowe źródło dochodu.

${ }^{10}$ Zachowaniu niektórych uprawnień w razie zmiany zatrudnienia służyła tzw. ciągłość pracy. Zob. P. Walorska, Staż pracy, Warszawa 2014, s. 105 i nast. oraz przytoczone tam piśmiennictwo.

${ }^{11} \mathrm{Na}$ temat charakterystyki ubezpieczeń społecznych zob. zwłaszcza: I. Jędrasik-Jankowska, Pojęcia i konstrukcje prawne ubezpieczenia społecznego, wyd. 5, Warszawa 2013, s. 25 i nast.

${ }_{12}$ Tak np. T. Zieliński, Ubezpieczenia społeczne pracowników, Warszawa - Kraków 1994, s. 167 i nast.

${ }^{13} \mathrm{~W}$ ujęciu historycznym zob. np. W. Szubert, Ubezpieczenie społeczne. Zarys systemu, Warszawa 1987, s. 125 i nast.; B. Wagner, Ewolucja regulacji prawnej ubezpieczeń społecznych, [w:] Problemy prawa ubezpieczeń społecznych, red. B. Wagner, Kraków 1996, s. 9 i nast. 


\section{3.}

Obecne uwarunkowania rynku pracy są zasadniczo odmienne od zarysowanych powyżej. Stopniowym przeobrażeniom uległy regulacje prawne, a zarazem postęp technologiczny oraz procesy globalizacyjne spowodowały powstanie nowych zjawisk i problemów. Całościowe omówienie ewolucji naszego ustawodawstwa pracy po przełomie z 1989 r. przekraczałoby ramy niniejszego opracowania. ${ }^{14}$ Warto jednak zasygnalizować, że nowością, która pojawiła się tuż po zmianie ustroju, stały się przepisy o zwolnieniach grupowych oraz upadłości i likwidacji pracodawcy, a oblicze rynku pracy zostało całkowicie odmienione wraz z pojawieniem się na szeroką skalę bezrobocia. Kodeks pracy był wielokrotnie nowelizowany, a wśród jego przekształceń najistotniejsze znaczenie miały obszerne zmiany z $1989^{15}, 1996^{16}$ oraz $2003 \mathrm{rr}^{17}$

Wraz z rozwojem gospodarki rynkowej zasadnicze zmiany zaszły w kwestii roli i znaczenia umowy na czas określony. Ideą tego rodzaju umowy o pracę jest zapewnienie stabilizacji zatrudnienia. ${ }^{18}$ Już $\mathrm{w}$ chwili zawierania umowy strony określają moment jej ustania, ale umowa powinna trwać do nadejścia uzgodnionego terminu. $Z$ teoretycznego punktu widzenia wcześniejsze jednostronne wypowiedzenie umowy na czas określony powinno być wyjątkiem. W rzeczywistości ukształtowała się zupełnie inna praktyka. Co do zasady umowy o pracę na czas określony zawierają klauzule o dopuszczalności jej rozwiązania przez którąś ze stron, co jest przedmiotem wspomnianego wyżej art. 33 k.p. Nie jest wówczas wymagane wskazanie przyczyny wypowiedzenia, działania pracodawcy nie są przedmiotem konsultacji związkowej, a okres wypowiedzenia wynosi dwa tygodnie niezależnie od stażu pracy. Zwolnionemu pracownikowi nie przysługuje roszczenie o przywrócenie do pracy. Ponadto Kodeks pracy nie ustanowił górnego limitu trwania umowy o pracę na czas określony, po której przekształcałaby się ona w umowę na czas nieokreślony.

Sens długoletniej umowy o pracę na czas określony jest porównywalny z założeniami umowy bezterminowej. Dlatego wysoce negatywnie należy ocenić

${ }^{14}$ Kwestie te omawiają np. M. Skąpski, Ochronna funkcja prawa pracy $w$ gospodarce rynkowej, Warszawa 2006, s. 19 i nast.; H. Szurgacz, Polskie prawo pracy po upadku socjalizmu. Kilka uwag o kierunkach rozwoju, [w:] Człowiek, obywatel, pracownik. Studia z zakresu prawa. Ksiegga jubileuszowa poświęcona Profesor Urszuli Jackowiak, red. J. Stelina, A. Wypych-Żywicka, „Gdańskie Studia Prawnicze" 2007, t. XVII, s. 245 i nast.

${ }^{15}$ Ustawa z dnia 7 kwietnia 1989 r. o zmianie ustawy - Kodeks pracy oraz o zmianie niektórych ustaw, Dz. U. z 1989 r., nr 20, poz. 107.

${ }^{16}$ Ustawa z dnia 2 lutego 1996 r. o zmianie ustawy - Kodeks pracy oraz o zmianie niektórych ustaw, Dz. U. z 1996 r., nr 24, poz. 110.

${ }^{17}$ Ustawa z dnia 14 listopada 2003 r. o zmianie ustawy - Kodeks pracy oraz o zmianie niektórych innych ustaw, Dz. U. z 2003 r., nr 213, poz. 2081.

${ }^{18}$ B. Wagner, Terminowe umowy o prace, Warszawa 1980, s. 38. 
fakt, że pracownik zatrudniony na podstawie takiej umowy w praktyce nie korzysta z żadnej ochrony przed wypowiedzeniem. Skutecznej ochrony nie gwarantuje również art. $25^{1}$ k.p., w świetle którego trzecia umowa na czas określony może ulec przekształceniu w bezterminową umowę o pracę. Problem braku stabilizacji zatrudnienia należy również zasygnalizować $\mathrm{w}$ odniesieniu do umowy zawartej w celu zastępstwa pracownika podczas jego usprawiedliwionej nieobecności w pracy (art. $33^{1}$ k.p.). ${ }^{19}$

Nic więc dziwnego, że umowy o pracę na czas określony cieszą się dużą popularnością wśród pracodawców. Dla podmiotu zatrudniającego szczególnie wygodna jest możliwość szybkiego rozwiązania takiej umowy. W praktyce prowadzi to do licznych nadużyć oraz patologii na rynku pracy. Odsetek umów terminowych w Polsce należy do najwyższych w Unii Europejskiej. Należy przy tym zasygnalizować zaawansowane prace legislacyjne w kwestii nowego uregulowania problematyki umów na czas określony. Impulsem dla podjęcia prac stało się zwłaszcza stwierdzenie przez Komisję Europejską niezgodności prawa polskiego z dyrektywą 99/7020, co nastąpiło na skutek skargi złożonej przez NSZZ ,Solidarność", a także orzeczenie Trybunału Sprawiedliwości Unii Europejskiej w sprawie Nierodzik, dotyczącego okresów wypowiedzenia umowy na czas określony. ${ }^{21}$ Należy oczekiwać, że nowe uregulowania wzmocnią stabilizację zatrudnienia pracowników zatrudnionych na podstawie terminowych umów o pracę.

Niezależnie od istnienia tradycyjnych umów o pracę, na rynku pracy pojawily się nowe formy prawne zatrudnienia. W pierwszym rzędzie chodzi o funkcjonowanie agencji pracy tymczasowej, które kierują pracowników tymczasowych do wykonywania pracy tymczasowej na rzecz pracodawcy użytkownika. Wskazana forma aktywności zarobkowej jest przedmiotem ustawy z dnia 9 lipca $2003 \mathrm{r}$. o zatrudnianiu pracowników tymczasowych. ${ }^{22}$ Co do zasady agencja zatrudnia pracowników tymczasowych na podstawie umowy o pracę na czas określony lub na czas wykonania określonej pracy (art. 7 ustawy). Należy mieć na uwadze, że przejściowy charakter zatrudnienia jest $\mathrm{w}$ pewnym sensie wpisany $\mathrm{w}$ istotę działalności agencji pracy tymczasowej. Kolejną nową formą zatrudnienia, uregulowaną przez ustawodawstwo, jest telepraca. Nastąpiło to nowelizacją kodeksu

${ }^{19} \mathrm{~W}$ najnowszym piśmiennictwie zob. M. Rylski, Ochrona pracownika przed nadużywaniem terminowego zatrudnienia, „Praca i Zabezpieczenie Społeczne” 2014, nr 8, s. 2 i nast.

${ }^{20}$ Dyrektywa Rady 99/70/WE z dnia 28 czerwca 1999 r. dotycząca porozumienia ramowego w sprawie pracy na czas określony, zawartego przez Europejską Unię Konfederacji Przemysłowych i Pracodawców (UNICE), Europejskie Centrum Przedsiębiorstw Publicznych (CEEP) oraz Europejską Konfederację Związków Zawodowych (ETUC), Dziennik Urzędowy WE nr L 175 z 10 lipca 1999 r., s. 43 (Dz. Urz. UE, wyd. sp., rozdz. 5, t. III, 368).

${ }^{21}$ Wyrok z dnia 13 marca 2014 r. w sprawie C-38/13 Małgorzata Nierodzik przeciwko Samodzielny Publiczny Psychiatryczny Zakład Opieki Zdrowotnej im. dr. Stanisława Deresza w Choroszczy, jeszcze nieopublikowany w Zbiorze Orzecznictwa TSUE.

${ }^{22}$ Dz. U. z 2003 r., nr 166, poz. 1608. 
z dnia 24 sierpnia 2007 r. ${ }^{23}$ Zgodnie z art. $67^{5} \S 1$ k.p. praca może być wykonywana regularnie poza zakładem pracy, z wykorzystaniem środków komunikacji elektronicznej w rozumieniu przepisów o świadczeniu usług drogą elektroniczną (telepraca). Z kolei na gruncie art. $67^{5} \S 2$ k.p. telepracownikiem jest pracownik, który wykonuje pracę we wskazanych wyżej warunkach i przekazuje pracodawcy wyniki pracy, w szczególności za pośrednictwem środków komunikacji elektronicznej. Telepraca może być świadczona na podstawie umowy o pracę każdego rodzaju, co z kolei determinuje dopuszczalność jej wypowiedzenia.

Wskazanym kategoriom osób świadczących pracę przysługuje status pracowniczy, zarówno w rozumieniu art. 2 k.p., jak i art. 6 ust. 1 pkt 1 oraz art. 8 ust. 1 ustawy z dnia 13 października 1998 r. o systemie ubezpieczeń społecznych. ${ }^{24}$ W konsekwencji są oni objęci obowiązkowym ubezpieczeniem emerytalnym, rentowym, chorobowym (obejmującym świadczenia $\mathrm{w}$ razie choroby i macierzyństwa) oraz wypadkowym (dotyczącym wypadków przy pracy i chorób zawodowych). ${ }^{25}$ Przysługuje im zatem pełna ochrona przewidziana przez nasz system ubezpieczeń społecznych.

Odrębną kwestią jest status osób świadczących pracę poza stosunkiem pracy, w tym zwłaszcza na podstawie umów cywilnoprawnych. ${ }^{26}$ Zjawisko to bywa nazywane ,zatrudnieniem cywilnoprawnym”. Rzecz jasna, dopuszczalność zarobkowania na takiej podstawie prawnej sama w sobie nie budzi żadnych wątpliwości. Problem pojawia się wówczas, gdy umowa cywilnoprawna, najczęściej umowa zlecenia lub umowa agencyjna, jest wykonywana w dłuższym przedziale czasowym, w warunkach podporządkowania organizacyjnego. $\mathrm{Z}$ reguły mamy wówczas do czynienia $\mathrm{z}$ obejściem przepisów prawa pracy. Taka forma działalności zarobkowej jest niezwykle dogodna dla podmiotu zatrudniającego. Może on jednostronnie zakończyć umowę w dowolnym momencie, a zarazem unika szeregu obciążeń finansowych. W praktyce zresztą wysokie koszty pracy są jednym z głównych powodów ucieczki od prawa pracy na rzecz umów cywilnoprawnych.

$\mathrm{Z}$ drugiej strony zleceniobiorcy nie przysługuje żadna ochrona z zakresu prawa pracy (np. dodatek za pracę w godzinach nadliczbowych czy prawo do urlopu wypoczynkowego), nawet jeśli umowa zlecenia stanowi główne lub jedyne źródło jego utrzymania. Umowa cywilnoprawna nie gwarantuje również żadnej stabilizacji stosunku prawnego. Ponadto w porównaniu z pracownikami węższy jest zakres ochrony ubezpieczeniowej. Niższa jest podstawa wymiaru składek,

${ }^{23}$ Dz. U. z 2007 r., nr 181, poz. 1288.

${ }^{24}$ T.j. Dz. U. z 2013 r., poz. 1442 ze zm.

${ }^{25}$ Szerzej B. Gudowska, [w:] Ustawa o systemie ubezpieczeń społecznych. Komentarz, red. B. Gudowska, J. Strusińska-Żukowska, Warszawa 2011, s. 171 i nast.

${ }^{26}$ Zob. np. A. Musiała, Zatrudnienie niepracownicze, Warszawa 2011, s. 78 i nast. oraz przytoczone piśmiennictwo. 
ubezpieczenia chorobowe są dobrowolne, de lege lata obowiązuje również szereg zwolnień z obowiązku ubezpieczenia. ${ }^{27}$ Jednocześnie w rozumieniu ustawy o systemie ubezpieczeń społecznych pracownikiem jest osoba wykonująca pracę na podstawie umowy cywilnoprawnej, jeżeli umowa taka została zawarta z pracodawcą, $\mathrm{z}$ którym pozostaje ona w stosunku pracy (art. 8 ust. 2a ustawy). Inaczej mówiąc, umowa cywilnoprawna istniejąca między tymi samymi stronami „równolegle" z umową o pracę, pod kątem ubezpieczeń społecznych jest traktowana jak umowa o pracę. Ma to znaczenie zarówno dla podlegania obowiązkowi ubezpieczeń i uiszczaniu składek, jak i w kwestii prawa do świadczeń. W praktyce uregulowanie to obejmuje relatywnie niewielką grupę osób świadczących pracę na podstawie umów cywilnoprawnych.

Należy skrótowo zasygnalizować jeszcze jedną formę prowadzenia działalności zarobkowej, występującą na rynku pracy. Jest nią praca na własny rachunek, określana również jako samozatrudnienie. Brak jest spójnej i wyczerpującej regulacji prawnej, a nawet jednoznacznej definicji tego zjawiska. ${ }^{28}$ Bez wątpienia aktywność tego rodzaju może stanowić alternatywę dla bezrobocia. Nie budzi zastrzeżeń model samodzielnej działalności zarobkowej oparty na tym, że dana osoba świadczy usługi na rzecz różnych podmiotów. Niemniej faktyczne uzależnienie ekonomiczne osoby samozatrudnionej od jednego kontrahenta może prowadzić do powstania „pozornego samozatrudnienia”, a w rezultacie do obchodzenia prawa pracy. Przepisy ubezpieczeń społecznych posługują się terminem „osoba prowadząca pozarolniczą działalność” (art. 6 ust. 1 pkt 5 oraz art. 8 ust. 6 ustawy o systemie ubezpieczeń społecznych). Podmioty takie objęte są obowiązkowym ubezpieczeniem emerytalnym, rentowym i wypadkowym, ponadto moga dobrowolnie przystąpić do ubezpieczenia chorobowego. ${ }^{29}$ Dopiero przystąpienie $\mathrm{z}$ woli danej osoby do ubezpieczenia chorobowego zagwarantuje jej prawo do zasiłku chorobowego oraz macierzyńskiego.

Obraz współczesnego rynku pracy w Polsce jest zatem złożony. Równolegle funkcjonują na nim odmienne formy świadczenia pracy, a zróżnicowanie to coraz bardziej się pogłębia. Najistotniejszą cechą naszego rynku pracy jest jego głęboka segmentacja. Można mówić o dychotomicznym podziale na pracowników oraz inne osoby świadczące pracę zarobkową. $Z$ jednej strony mamy pracowników

${ }^{27}$ I. Jędrasik-Jankowska, op. cit., s. 62 i nast.

${ }^{28}$ Szerzej: M. Skąpski, Problem pojęcia i prawnej regulacji samozatrudnienia, [w:] Stosunki zatrudnienia $w$ dwudziestoleciu społecznej gospodarki rynkowej. Księga pamiatkowa z okazji jubileuszu 40-lecia pracy naukowej Profesor Barbary Wagner, red. A. Sobczyk, Warszawa 2010, s. 85 i nast.

${ }^{29}$ B. Gudowska, op. cit., s. 208 i nast. 
w rozumieniu art. 2 k.p., którzy w oparciu o swój status zawodowy korzystają z pełnej ochrony w dziedzinie ubezpieczeń społecznych. Kategoria ta jest zresztą wewnętrznie niejednolita. Pracowników zatrudnionych bezterminowo obejmuje bowiem stabilizacja stosunku pracy, co w praktyce nie znajduje odniesienia do licznej grupy pracowników zatrudnionych na podstawie umów na czas określony. $\mathrm{Z}$ drugiej strony występuje szereg różnego rodzaju form aktywności zarobkowej poza stosunkiem pracy. Osoby takie nie korzystają z żadnej stabilizacji odnośnie prowadzonej przez siebie działalności, a ochrona ubezpieczeniowa jest zdecydowanie mniejsza w porównaniu z pracownikami. Jest to szczególnie widoczne w kontekście długoterminowych umów cywilnoprawnych.

W konsekwencji pracownicy zatrudnieni na podstawie umowy na czas nieokreślony stanowią de facto uprzywilejowaną kategorię uczestników rynku pracy. W odniesieniu do pozostałych podmiotów dominującą cechą ich sytuacji życiowej jest niepewność. Dotyczy ona zarówno bieżącej chwili oraz regularności uzyskiwanego dochodu, jak i dłuższej perspektywy czasowej. W literaturze tę grupę społeczną coraz częściej określa się mianem prekariatu, biorąc pod uwagę właśnie brak stabilizacji i odpowiedniego zabezpieczenia socjalnego. Zarysowane zjawiska występują mimo wykonywania pracy zarobkowej, nierzadko przez osoby legitymujące się wysokimi kwalifikacjami. ${ }^{30}$

Z powyższych względów celowe jest przeprowadzenie systemowych zmian legislacyjnych dotyczących statusu osób zatrudnionych. Argumentów za przezwyciężeniem wskazanych różnic dostarcza Konstytucja RP, na gruncie której pojęcie ,pracownik" ma zakres podmiotowy wykraczający poza stosunek pracy. ${ }^{31}$ Ponadto zakres podstawowych praw społecznych, choćby na gruncie Karty Praw Podstawowych Unii Europejskiej, powinien być rozumiany szeroko. Nie może on być ograniczony do klasycznego zatrudnienia w ramach stosunku pracy. ${ }^{32}$ Inaczej mówiąc, punktem wyjścia dla ochrony osoby prowadzącej działalność zarobkową powinien być nie tyle status zawodowy, co godność istoty ludzkiej i wywodzące się stąd prawa człowieka. ${ }^{33} \mathrm{~W}$ doktrynie sygnalizowane są obszary, w których

${ }^{30}$ Szerzej np. A. Patulski, Praca niepewna jako produkt zmian na współczesnym rynku pracy, [w:] Prawo pracy. Refleksje i poszukiwania. Ksiega jubileuszowa Profesora Jerzego Wratnego, red. G. Uścińska, Warszawa 2013, s. 87 i nast.; B. Godlewska-Bujok, Prekariat a umowy prekaryjne. Głos w dyskusji, „Praca i Zabezpieczenie Społeczne” 2014, nr 9, s. 2 i nast. oraz przytoczone piśmiennictwo. Socjologiczną analizę zachodzących procesów przedstawia G. Standing, Prekariat. Nowa niebezpieczna klasa, Warszawa 2014, s. 33 i nast.

${ }^{31}$ Zob. zwłaszcza: A. Sobczyk, Prawo pracy w świetle Konstytucji RP, t. I: Teoria publicznego i prywatnego indywidualnego prawa pracy, Warszawa 2013, s. 68. Autor ten krytykuje zjawisko „pracowniczocentryzmu” w analizie prawa pracy oraz wskazuje jego negatywne skutki (s. 27 i nast.).

${ }^{32}$ L. Mitrus, Prawa społeczne w Karcie Praw Podstawowych Unii Europejskiej, „Państwo i Prawo" 2013, nr 7, s. 26-27.

${ }^{33}$ A. Sobczyk, Prawo i człowiek pracujący - między ochrona godności a równości, [w:] Ak- 
konieczność wprowadzenia zmian jest szczególnie nagląca. Postulaty te dotyczą przykładowo ochrony przysługującej stronom umów cywilnoprawnych ${ }^{34}$, minimalnego wynagrodzenia zleceniobiorców ${ }^{35}$, a także możliwości zrzeszania się przez nich $\mathrm{w}$ związki zawodowe ${ }^{36}$ oraz prowadzenia sporów zbiorowych. ${ }^{37}$ Formułowane są głosy dotyczące celowości wyodrębnienia „prawa zatrudnienia” jako szerszej niż prawo pracy gałęzi ustawodawstwa, obejmującej również zatrudnienie niepracownicze. ${ }^{38}$

Odnotować należy również uwarunkowania zewnętrzne krajowego rynku pracy. W ramach strategii Unii Europejskiej na rzecz zatrudnienia i wzrostu gospodarczego „Europa 2020” w odniesieniu do naszego kraju zostało wydane zalecenie Rady z dnia 8 lipca 2014 r. w sprawie krajowego programu reform dla Polski na 2015 r. oraz zawierające opinię Rady na temat przedstawionego przez Polskę programu konwergencji na $2014 \mathrm{r}^{39}$ Działania sugerowane na lata 2014-2015 obejmują m.in. ,zwalczanie segmentacji rynku pracy przez zwiększenie wysiłków na rzecz zapewnienia łatwiejszego przechodzenia z zatrudnienia na czas określony do stałego zatrudnienia oraz przez ograniczenie nadmiernego wykorzystywania umów cywilnoprawnych" (pkt 2 zalecenia). Zatem impulsem dla podejmowania działań legislacyjnych dotyczących rynku pracy może być nie tylko niezgodność z prawem unijnym regulacji wewnętrznych w kwestii umów terminowych, ale też unijne dążenia do koordynacji polityki gospodarczej państw członkowskich.

Na chwilę obecną brak jest spójnej i całościowej wizji przekształceń rynku pracy. Należy jednak zasygnalizować pewne zmiany cząstkowe, które zostały wprowadzone w ostatnim okresie. Ustawa z dnia 29 sierpnia 2014 r. o zmianie ustawy - Prawo zamówień publicznych ${ }^{40}$ uznała stosowanie zatrudnienia pracowniczego przez podmioty ubiegające się o zamówienia publiczne za jedno z kryte-

sjologiczne podstawy prawa pracy i ubezpieczeń społecznych, red. M. Skąpski, K. Ślebzak, Poznań 2014, s. 40 i nast.

${ }^{34}$ Zob. zwłaszcza: T. Liszcz, Prawna ochrona niepracowniczego zatrudnienia na podstawie umowy wedtug projektu kodeksu pracy, [w:] Jedność w różnorodności. Studia z zakresu prawa pracy, zabezpieczenia społecznego i polityki społecznej. Ksiegga pamiątkowa dedykowana Profesorowi Wojciechowi Muszalskiemu, red. A. Patulski, K. Walczak, Warszawa 2009, s. 177 i nast.

${ }^{35}$ A. Sobczyk, Wynagrodzenie minimalne zleceniobiorców, „Praca i Zabezpieczenie Społeczne" 2012, nr 8, s. 5 i nast.

${ }^{36}$ E. Podgórska-Rakiel, Konieczność nowelizacji prawa polskiego w kwestii wolności związkowych z perspektywy Międzynarodowej Organizacji Pracy, „Monitor Prawa Pracy” 2014, nr 10, s. 510 i nast.

${ }^{37}$ M. Kurzynoga, Prawo do wszczęcia sporu zbiorowego oraz prawo do akcji zbiorowych osób zarobkowo wykonujacych prace niebędacych pracownikami, „Monitor Prawa Pracy” 2014, nr 12, s. 622 i nast.

${ }^{38}$ M. Gersdorf, Prawo zatrudnienia, Warszawa 2013, s. 169 i nast.

${ }^{39}$ Dz. Urz. UE z 29 lipca 2014 r., C 247, s. 97.

${ }^{40}$ Dz. U. z 2014 r., poz. 1232 
riów ich przyznawania. Z kolei ustawa z dnia 23 października 2014 r. o zmianie ustawy o systemie ubezpieczeń społecznych ${ }^{41}$ wprowadziła nowe uregulowania dotyczące umów zlecenia. Począwszy od 2016 r. składki ubezpieczeniowe będą odprowadzane od wszystkich umów zlecenia, a podstawą ich wymiaru ma być minimalne wynagrodzenie za pracę. ${ }^{42} \mathrm{Z}$ jednej strony pozwoli to na szersze objęcie ochroną ubezpieczeniową osób prowadzących działalność zarobkową na podstawie umów cywilnoprawnych i zwiększy wpływy finansowe Zakładu Ubezpieczeń Społecznych. Z drugiej natomiast nowelizacja zmniejsza różnice kosztów pracy pomiędzy działalnością wykonywaną na podstawie umów o pracę a umów cywilnoprawnych, który to element stanowi jeden z głównych motywów ucieczki od zatrudnienia pracowniczego. Jak sądzę, co do zasady zmiany te należy ocenić pozytywnie. Różnego rodzaju zachęty, w tym fiskalne (np. zmniejszanie różnic pomiędzy obciążeniami finansowymi umów różnego typu), mogą okazać się skuteczniejszą metodą zwalczania segmentacji rynku pracy niż sankcje za naruszenie obowiązujących przepisów, np. odpowiedzialność za wykroczenie z art. 281 pkt 1 k.p.

Konkludując, należy stwierdzić, że model ochrony socjalnej skoncentrowany wokół zatrudnienia na podstawie bezterminowej umowy o pracę nie odpowiada wymogom współczesności. Można było uznać go za adekwatny na gruncie gospodarki centralnie sterowanej, kiedy przytłaczająca większość osób świadczyła pracę zarobkową w ramach umowy o pracę na czas nieokreślony. Ustanowienie powszechnej ochrony przed wypowiedzeniem wraz z kodyfikacją prawa pracy było zasadniczą zmianą ówczesnego stanu prawnego. Przyjęte wówczas założenia obowiązują do dzisiaj, ale we współczesnych realiach ich konsekwencją jest głęboki podział uczestników rynku pracy na lepszych i gorszych. Wyznacznikiem stabilizacji zatrudnienia lub jej braku jest prawna forma świadczenia pracy. Oczywiście, w pewnym zakresie zróżnicowanie sytuacji osób zarobkujących jest zrozumiałe. Niemniej de lege lata różnice te są zbyt daleko idące, by przejść nad nimi do porządku dziennego. Istniejący stan prawny budzi zresztą uzasadnione poczucie niesprawiedliwości. ${ }^{43} \mathrm{~W}$ praktyce stabilizacja zatrudnienia staje się coraz bardziej przywilejem niż standardowym uprawnieniem osób świadczących pracę podporządkowaną.

${ }^{41}$ Dz. U. z 2014 r., poz. 1831.

${ }^{42}$ Ponadto od 1 stycznia 2015 r. obowiązkiem odprowadzania składek na ubezpieczenie społeczne objęte są dochody członków rad nadzorczych.

${ }^{43}$ Problematykę tę omawia obszernie T. Liszcz, W sprawie sprawiedliwości w prawie pracy, [w:] Aksjologiczne podstawy prawa pracy..., s. 111 i nast. 
Fundamentalne dylematy są również związane z szeroko rozumianym zabezpieczeniem społecznym. Wspomniałem wcześniej o niedostatkach ochrony zleceniobiorców oraz osób prowadzących działalność na własny rachunek. Warto również mieć na uwadze, że obowiązujący u nas model ochrony socjalnej oparty jest na technice ubezpieczeniowej. Poziom przyszłych świadczeń emerytalnych jest uzależniony od wysokości składek zewidencjonowanych na indywidualnym koncie ubezpieczonego podczas jego całej kariery zawodowej. Mobilność jest obecnie postrzegana jako pożądana cecha na rynku pracy. Jednym z jej skutków jest jednak fakt, że okresy aktywności zarobkowej często przerywane są okresami bezrobocia. Ponadto na różnych etapach życia działalność zarobkowa może być prowadzona na różnych podstawach prawnych, nierzadko za stosunkowo niewielkim wynagrodzeniem. Wszystkie te elementy powodują, że „zapracowanie” na godziwą emeryturę wcale nie jest oczywiste. Odrębnym zagadnieniem jest zresztą kwestia, czy w odniesieniu do zabezpieczenia z tytułu starości ubezpieczeniowy model ochrony nie powinien zostać w przyszłości zastąpiony techniką zaopatrzeniową.

Sądzę zatem, że stoimy w obliczu konieczności przeprowadzenia fundamentalnych zmian dotyczących rynku pracy, statusu prawnego osób prowadzących działalność zarobkową oraz ich ochrony socjalnej. W nieodległej perspektywie czasowej przekształcenia powinny objąć zarówno regulacje prawa pracy, jak i prawa ubezpieczeń społecznych.

\section{BIBLIOGRAFIA}

Dral A., Powszechna ochrona trwałości stosunku pracy. Tendencje zmian, Warszawa 2009.

Gersdorf M., Prawo zatrudnienia, Warszawa 2013.

Godlewska-Bujok B., Prekariat a umowy prekaryjne. Głos $w$ dyskusji, „Praca i Zabezpieczenie Społeczne" 2014, nr 9.

Gudowska B., [w:] Ustawa o systemie ubezpieczeń społecznych. Komentarz, red. B. Gudowska, J. Strusińska-Żukowska, Warszawa 2011.

Jaśkiewicz W., Zagadnienia ogólne kodeksu pracy, [w:] Studia nad kodeksem pracy, red. W. Jaśkiewicz, Poznań 1976.

Jędrasik-Jankowska I., Pojęcia i konstrukcje prawne ubezpieczenia społecznego, wyd. 5, Warszawa 2013.

Kurzynoga M., Prawo do wszczęcia sporu zbiorowego oraz prawo do akcji zbiorowych osób zarobkowo wykonujacych prace, niebędacych pracownikami, „Monitor Prawa Pracy” 2014, nr 12.

Lewandowski H., Nawiazanie stosunku pracy, [w:] Nowe prawo pracy, red. R. Korolec, J. Pacho, Warszawa 1975.

Liszcz T., Nieważność czynności prawnych w umownych stosunkach pracy, Warszawa 1977.

Liszcz T., Prawna ochrona niepracowniczego zatrudnienia na podstawie umowy wedtug projektu kodeksu pracy, [w:] Jedność w różnorodności. Studia z zakresu prawa pracy, zabezpieczenia społecznego i polityki społecznej. Księga pamiątkowa dedykowana Profesorowi Wojciechowi Muszalskiemu, red. A. Patulski, K. Walczak, Warszawa 2009. 
Liszcz T., W sprawie sprawiedliwości w prawie pracy, [w:] Aksjologiczne podstawy prawa pracy i ubezpieczeń społecznych, red. M. Skąpski, K. Ślebzak, Poznań 2014.

Mitrus L., Prawa społeczne w Karcie Praw Podstawowych Unii Europejskiej, „Państwo i Prawo” $2013, \mathrm{nr} 7$.

Musiała A., Zatrudnienie niepracownicze, Warszawa 2011.

Muszalski W., Polski kodeks pracy na tle kodyfikacji jego epoki, [w:] Prawo pracy w świetle procesów integracji europejskiej. Księga jubileuszowa Profesor Marii Matey-Tyrowicz, red. J. Wratny, M.B. Rycak, Warszawa 2011.

Pacho J., Przedmiot, system i funkcje prawa pracy, [w:] Nowe prawo pracy, red. R. Korolec, J. Pacho, Warszawa 1975.

Patulski A., Praca niepewna jako produkt zmian na wspótczesnym rynku pracy, [w:] Prawo pracy. Refleksje i poszukiwania. Księa jubileuszowa Profesora Jerzego Wratnego, red. G. Uścińska, Warszawa 2013.

Podgórska-Rakiel E., Konieczność nowelizacji prawa polskiego w kwestii wolności związowych z perspektywy Międzynarodowej Organizacji Pracy, „Monitor Prawa Pracy” 2014, nr 10.

Rycak A., Powszechna ochrona trwałości stosunku pracy, Warszawa 2013.

Rylski M., Ochrona pracownika przed nadużywaniem terminowego zatrudnienia, „Praca i Zabezpieczenie Społeczne" 2014, nr 8.

Skąpski M., Ochronna funkcja prawa pracy w gospodarce rynkowej, Warszawa 2006.

Skąpski M., Problem pojęcia i prawnej regulacji samozatrudnienia, [w:] Stosunki zatrudnienia $w$ dwudziestoleciu społecznej gospodarki rynkowej. Ksiega pamiatkowa z okazji jubileuszu 40-lecia pracy naukowej Profesor Barbary Wagner, red. A. Sobczyk, Warszawa 2010.

Sobczyk A., Prawo i człowiek pracujący - między ochrona godności a równości, [w:] Aksjologiczne podstawy prawa pracy i ubezpieczeń społecznych, red. M. Skąpski, K. Ślebzak, Poznań 2014.

Sobczyk A., Prawo pracy w świetle Konstytucji RP, t. I: Teoria publicznego i prywatnego indywidualnego prawa pracy, Warszawa 2013.

Sobczyk A., Wynagrodzenie minimalne zleceniobiorców, „Praca i Zabezpieczenie Społeczne” 2012, nr 8.

Standing G., Prekariat. Nowa niebezpieczna klasa, Warszawa 2014.

Szubert W., Ubezpieczenie spoleczne. Zarys systemu, Warszawa 1987.

Szurgacz H., Polskie prawo pracy po upadku socjalizmu. Kilka uwag o kierunkach rozwoju, [w:] Człowiek, obywatel, pracownik. Studia z zakresu prawa. Księga jubileuszowa poświęcona Profesor Urszuli Jackowiak, red. J. Stelina, A. Wypych-Żywicka, „Gdańskie Studia Prawnicze” 2007, t. XVII.

Wagner B., Ewolucja regulacji prawnej ubezpieczeń spolecznych, [w:] Problemy prawa ubezpieczeń spotecznych, red. B. Wagner, Kraków 1996.

Wagner B., Terminowe umowy o prace, Warszawa 1980.

Walas A., Prawo wypowiedzenia umowy o pracę, Kraków 1961.

Walorska P., Staż pracy, Warszawa 2014.

Zieliński T., Ubezpieczenia społeczne pracowników, Warszawa - Kraków 1994. 
Pobrane z czasopisma Studia Iuridica Lublinensia http://studiaiuridica.umes.pl Data: 26/04/2023 16:10:04

Praca zarobkowa a bezpieczeństwo socjalne (uwagi na tle przekształceń rynku pracy)

\section{SUMMARY}

The present elaboration is dedicated to the analysis of labour market transformation since the codification of Polish labour law to the present day. Author emphasizes that the legal form of paid activity determines the legal status of the person concerned, both with relation to stability of employment and social security protection. Under centrally planned economy, the employment contract for an indefinite duration constituted the basic form of paid activity. Currently, however, various forms of work performance co-exist, many of them remain outside the scope of labour law. Author indicates deep segmentation of current labor market. He also pays attention to the fact that paid work quite often ensures neither life stability nor proper social protection.

Keywords: paid work, employment relationship, new forms of employment, social security, labour market, precarious work 